\title{
How Close Are We to Self-Provisioning? A Look at the Livelihood Strategies of Rural Households in the Southern Andean Region of Colombia
}

\author{
Héctor Eduardo Hernández 1,2,3,*iD, Gustavo Adolfo Gutiérrez 1,2,4 , Isabel Gutiérrez-Montes ${ }^{5}$, \\ Juan Carlos Suárez 1,2,4 , Hernán J. Andrade ${ }^{6}$, Angie Paola Bernal ${ }^{1}$, Fernando Casanoves ${ }^{5}$ (D) \\ and Cornelia Butler Flora ${ }^{7, *}$
}

\section{check for}

updates

Citation: Hernández, H.E.; Gutiérrez, G.A.; Gutiérrez-Montes, I.; Suárez,

J.C.; Andrade, H.J.; Bernal, A.P.; Casanoves, F.; Flora, C.B. How Close Are We to Self-Provisioning? A Look at the Livelihood Strategies of Rural Households in the Southern Andean Region of Colombia. Sustainability 2022, 14, 2504. https://doi.org/ $10.3390 /$ su14052504

Academic Editor: Mario D'Amico

Received: 17 January 2022

Accepted: 15 February 2022

Published: 22 February 2022

Publisher's Note: MDPI stays neutral with regard to jurisdictional claims in published maps and institutional affiliations.

Copyright: (C) 2022 by the authors. Licensee MDPI, Basel, Switzerland. This article is an open access article distributed under the terms and conditions of the Creative Commons Attribution (CC BY) license (https:// creativecommons.org/licenses/by/ $4.0 /)$.
1 Facultad de Ingeniería, Universidad de la Amazonia, Florencia 180001, Colombia; g.gutierrez@udla.edu.co (G.A.G.); ju.suarez@udla.edu.co (J.C.S.); a.bernal@udla.edu.co (A.P.B.)

2 Grupo de Investigación en Agroecosistemas y Conservación en Bosques Amazónicos GAIA, Universidad de la Amazonia, Florencia 180002, Colombia

3 Facultad de Ingeniería Agronómica, Universidad del Tolima, Ibagué 730001, Colombia

4 Facultad de Ciencias Agropecuarias, Universidad de la Amazonia, Florencia 180001, Colombia

5 CATIE-Centro Agronómico Tropical de Investigación y Enseñanza, Turrialba 30501, Costa Rica; isabel.gutierrez@catie.ac.cr (I.G.-M.); casanoves@catie.ac.cr (F.C.)

6 Grupo de Investigación PROECUT, Facultad de Ingeniería Agronómica, Universidad del Tolima, Ibagué 730001, Colombia; hjandrade@ut.edu.co

7 Department of Sociology and Criminal Justice, Iowa State University, Ames, IA 50011-1070, USA

* Correspondence: heduardohn@gmail.com (H.E.H.); cflora@iastate.edu (C.B.F.)

\begin{abstract}
Production for self-provisioning contributes to food security in rural territories; however, studies have indicated that this capacity is limited. We analyzed the impact of livelihood strategies on self-provisioning conditions in 162 rural households in the department of Huila, Colombia. We analyzed: a. source of foods; b. composition of home gardens; c. push and pull factors towards self-provisioning. We found that rural households are $79 \%$ dependent on grocery stores for their food. Only $51 \%$ of households have a home garden, with limited plant species diversity. Capacity for self-provisioning varies according to the livelihood strategies and capitals endowment of the household. Those households with a greater diversity of agricultural activities have higher capacity for self-provisioning. Conditions that are often the main objective of rural development programs, such as improving the economic income of families, turn out to be contradictory to the capacity to produce the food itself. For example, the larger the area to grow crops or keep livestock and the better the economic income, the greater the external dependence on food.
\end{abstract}

Keywords: peasant agriculture; food security; agricultural production; home gardens; resilience

\section{Introduction}

Although the world is largely dependent on markets to meet its food needs, a significant number of rural households, mainly in developing countries, are highly dependent on their own food production [1]. This practice is referred to as self-provisioning [2,3]. Surpluses from this production generate incomes that allow households to purchase other foods [4]. The actions derived from self-provisioning strengthen connections among family members and neighbors [2] through reciprocal exchange and donation of food [5]. In addition, self-provisioning improves food security through food diversity and the maintenance of healthy food habits [6].

Self-provisioning can be generated through different production processes, such as local processing, using harvest surpluses for home consumption [5], and family agriculture or the home gardens [7]. The latter favors the valuation of the social, environmental, and cultural dimensions of rural households and offers direct access to food, which are 
characteristics of food security [4]. Family agriculture with an agroecological approach goes beyond the production of healthy and sufficient food [8], and promotes the conservation of the natural base of diverse ecosystems, the empowerment of local actors [9], and allows agricultural production to form part of the livelihood strategies of rural households [10,11].

Diverse family farms produce grains, vegetables, fruits, fodder, and animal products simultaneously [12]. These foods are traditionally produced in home gardens and agroforestry systems [13]. Home gardens increase the intake of fresh and nutritious vegetables [14,15], particularly in more vulnerable households [16], supply of medicinal plants [17], exchange of seeds and seedlings [18], and decrease the acquisition of food in local markets [19]. These production systems encourage the participation of men and women of different ages, both in the home garden management and in food processing [20,21] and facilitates adaptation to social change in the community [22].

In the 1930s, the first studies of mixed (home) gardens were carried out in Java, Indonesia [23]. Since then, research has evolved in both definitions, which in English have addressed terms such as "home garden", "backyard gardens", "dooryard gardens", "kitchen gardens", and "house gardens" [24], and in the inventory of species, functions, structural characteristics, composition, and socio-economic and cultural relevance [23]. In turn, studies associate this work as an activist practice in Central Europe, with positive social, health, and environmental results [25]. Vávra et al. [26] found in a study of 775 food-producing households in the Czech Republic that home food production compared to conventional agribusiness production generates GHG emission savings of $42-92 \mathrm{~kg} \mathrm{CO} 2$ eq/person/year. Home gardens refer to an orchard or plot associated with the dwelling, in which shrubs and herbs grow, mixed with annual crops and the raising of domestic animals. When the tree component is associated with the perennial woody component, this garden can be configured within the concept of agroforestry [27].

Although the importance of home gardens in the food system is recognized [28], each context requires comprehensive and interdisciplinary research to explore its agrobiodiversity [29] and its contribution to self-provisioning. Eroza et al. [30] indicates that home gardens are a practice that has diminished over time and lost cultural value, a situation that compromises the food security of rural communities. The expansion of monocultures in tropical landscapes, to the detriment of home gardens, threatens the agrobiodiversity that for years has sustained peasant agriculture [31]. According to FAO, "food security exists when all people, at all times, have physical, social and economic access to sufficient, safe and nutritious food that meets their daily energy needs and food preferences for an active and healthy life" [32]. However, the lack of self-provisioning does not necessarily generate food insecurity, since food can be accessed through the market, requiring income from a variety of sources, including off-farm work [1]. Phenomena, such as disasters and crises, caused by adverse weather conditions, natural hazards, economic crises, and conflicts can alter access to food [33].

This document analyzes the impact of livelihood strategies on conditions of selfprovisioning in rural households in the department of Huila, Colombia. Guiding questions are: a. What is the source of access to food consumed in rural households? $\mathrm{b}$. What foods are grown in rural home gardens? c. What are the factors that enhance or detract from self-sufficiency in rural households? The study proposes, through the community capital framework, to take a first step in a more comprehensive analysis to measure the contribution of different rural livelihoods strategies to self-sufficiency. It is expected to provide a scientific basis for decision making regarding institutional efforts to strengthen food and nutritional security of peasant families, both in Colombia and elsewhere in the world. It is also expected to generate new research questions regarding agricultural production models and their impact on the food sovereignty of rural communities.

\section{Materials and Methods}

This study was conducted with 162 rural households in ten municipalities of the department of Huila, Colombia (Algeciras, Campoalegre, Íquira, Palermo, Rivera, Gigante, 
Tarqui, Hobo, Baraya, and Tello) (Figure 1). These municipalities cover different climates: warm semi-arid, temperate semi-humid, temperate semi-arid, desert warm, warm semihumid, cold humid, cold semi-arid, and temperate humid (Climatic Classification CaldasLang) [34]. We selected the department of Huila because dedicating $53 \%$ of its territory to agricultural activities, it has about $32 \%$ of the population with unsatisfied basic needs [35]; conditions that are closely related to the processes of food security through self-provisioning.

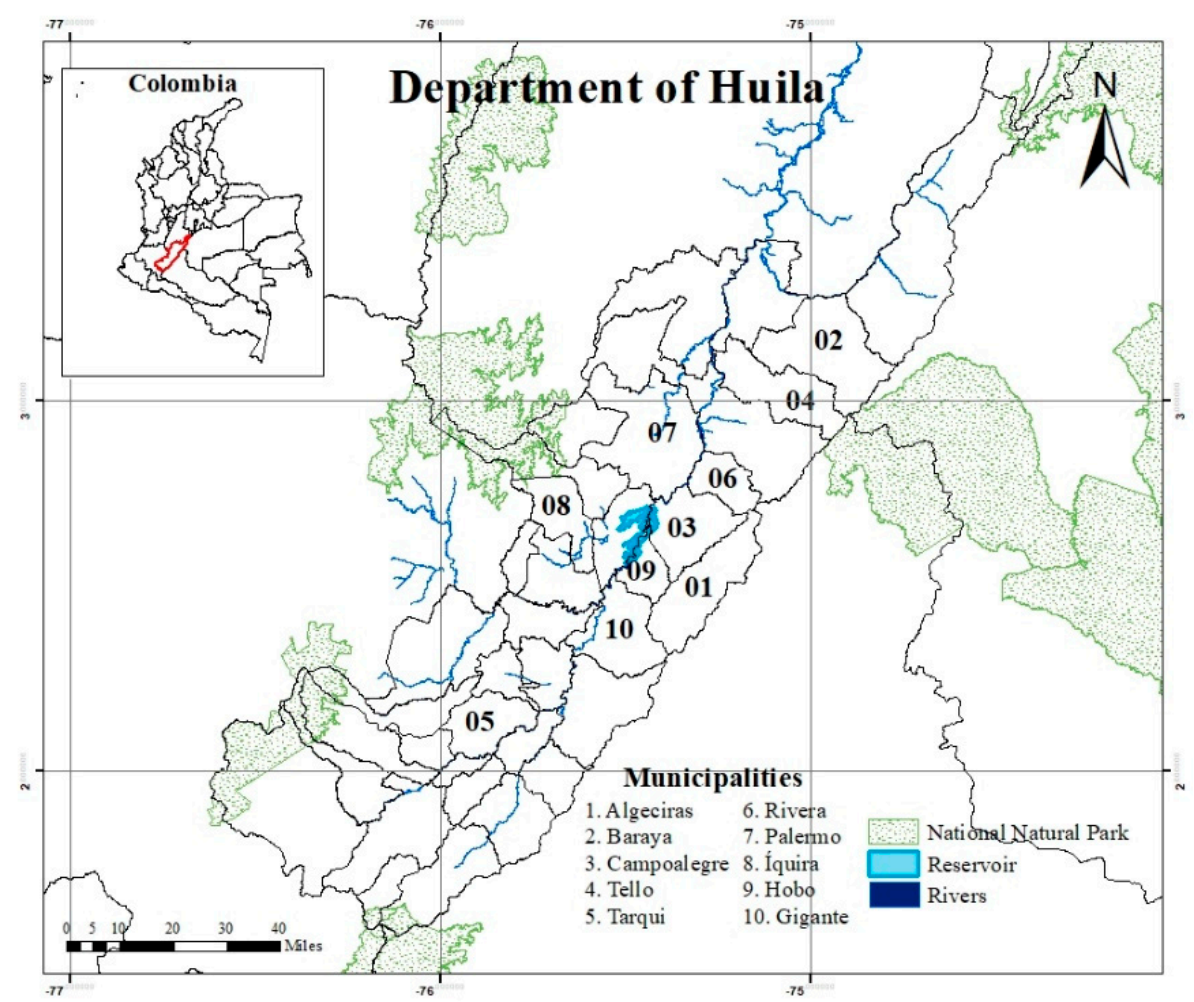

Figure 1. Area of study and selected municipalities in the department of Huila, Colombia.

Households were systematically selected, identifying households with different livelihood strategies in each municipality. These households correspond to seven types that were previously classified according to their livelihood strategies by Bernal et al. (unpublished data) [36] (Table 1). Semi-structured surveys with each household were carried out between 2018 and 2019 to collect information on: a. access to food; b. composition and diversity of home gardens; and c. factors that influence the characteristics of self-provisioning; for this purpose, questions were generated to characterize the seven household capitals proposed by Flora et al. [37] and used in different research studies [38-43].

Table 1. Types of rural households according to livelihood strategies in department of Huila, Colombia.

\begin{tabular}{|c|c|c|}
\hline Household Type & Abbreviation & Characteristics \\
\hline Cattlemen Cocoa Farmers & $\mathrm{CCF}$ & $\begin{array}{l}\text { Rural households whose farm area is larger than average ( }>30 \mathrm{ha} \text { ). Overall, } \\
68 \% \text { of the area is pasture, } 20 \% \text { is cocoa crops, and } 10 \% \text { is forests. }\end{array}$ \\
\hline Coffee Farmers & CofF & $\begin{array}{l}\text { Overall, } 30 \% \text { of the coffee farmers have farms with areas between } 8 \text { and } 16 \text { ha } \\
\text { and the rest of them do not exceed } 8 \text { ha. The main product is coffee ( } 46 \% \text { of the } \\
\text { income), followed by cocoa ( } 37 \% \text { of the income), and in some cases they } \\
\text { complement it with cattle raising as a form of saving ( } 5 \% \text { of the income). }\end{array}$ \\
\hline Cocoa Farmers & $\mathrm{CoF}$ & $\begin{array}{l}\text { They are economically dependent }(95 \%) \text { on cocoa. Overall, } 85 \% \text { of the farm's } \\
\text { area is established in cocoa crops, the rest is conserved in secondary forests or } \\
\text { fallows } 13 \% \text { of cocoa farmers have farms with between } 7 \text { and } 17 \text { ha, the rest of } \\
\text { the farms have no more than } 7 \text { ha. }\end{array}$ \\
\hline
\end{tabular}


Table 1. Cont.

\begin{tabular}{|c|c|c|}
\hline Household Type & Abbreviation & Characteristics \\
\hline Diversified Farmers & DF & $\begin{array}{l}\text { They have farms with areas averaging } 5 \text { ha. Overall, } 30 \% \text { of the area is in fruit } \\
\text { crops, such as grapes, avocado, tangerine, banana; } 70 \% \text { of the area is } \\
\text { established in cocoa crops. These activities contribute approximately } 45 \text { and } \\
40 \% \text { of the economic income, respectively, and } 15 \% \text { is complemented by the } \\
\text { production of eggs and transitory crops. }\end{array}$ \\
\hline Livestock Cocoa Farmers & $\mathrm{LiCF}$ & $\begin{array}{l}\text { The main economic activity is the production of minor species such as fish, } \\
\text { pigs, and chickens, which provides } 46 \% \text { of the income. In addition, they grow } \\
\text { cocoa in } 70 \% \text { of the farm area, which on average is } 8 \text { ha. The income received } \\
\text { from cocoa crops represents } 44 \% \text { of household income. }\end{array}$ \\
\hline Employees Cocoa Farmers & ECF & $\begin{array}{l}\text { The main sources of income are off-farm, including non-agricultural (i.e., } \\
\text { pensions, public employment, and own business) and agricultural activities, } \\
\text { such as sale of labor. These activities generate } 50 \% \text { of income. These } \\
\text { households produce cocoa throughout the farm ( } 3 \text { ha) and complement the } \\
\text { economy of these families by } 40 \% \text {. }\end{array}$ \\
\hline Landlords Cocoa Farmers & $\mathrm{LaCF}$ & $\begin{array}{l}\text { They base their economy on two activities: the sale of cocoa, for which they } \\
\text { allocate } 20 \% \text { of the farm area and the rest is used to be leased mainly for } \\
\text { livestock use, which contributes } 32 \% \text { to the economy of these households. }\end{array}$ \\
\hline
\end{tabular}

Source: (Bernal et al. unpublished data [36]).

\subsection{Access to Food in Rural Households}

Through a survey applied to each rural household, the source and percentage of food consumed was identified within the different types of households: grocery stores, neighbors, farmers' markets, and self-provisioning. The "grocery stores" category includes chain stores, supermarkets, mini-markets, local shops, and marketplaces. Some of these places are in rural areas (rural population centers), where families make food purchases. Most grocery stores are in urban areas. Usually, members of rural households travel on weekends to buy the foods in grocery stores in urban areas. Foods were classified as vegetables, fruits, grains, dairy products, and cereals. An analysis of variance (ANOVA) was used to determine the significant differences in the food source of each of the categories for each type of rural household. Continuous variables were analyzed through linear mixed models Di Rienzo et al. [44] to consider heterogeneous variances among rural household types. We used Fisher LSD $(p<0.05)$ to compare means after ANOVA. Analyses were performed using InfoStat statistical software version 2019 [45].

A binary indicator variable (presence $=1$, absence $=0$ ) was generated to determine whether the rural household grows the different foods (vegetables, fruits, grains, dairy products, and cereals). Using this food classification, a cluster analysis was performed using Ward's method and Gower's similarity [46]. After obtaining the clusters, we used an analysis of variance (ANOVA) to determine the quantitative variables that influenced cluster separation [46]. Four groups were classified according to the level of self-provisioning: null, low, medium, and high. Food access in the seven types of rural households was characterized by: a. reduced food quantity (RFQ); b. limited food variety (LFV); and c. going to bed without dinner because of lack of food (NHEF). The relationship between household types, level of self-provisioning and the capacity to access food using a multiple correspondence analysis [46] after testing hypothesis of independence using contingence tables.

\subsection{Composition and Diversity of Home Gardens in Rural Households}

The food species in the existing home gardens in each rural household were characterized, using variables: a. richness (number of plant species cultivated); b. diversity with the Shannon-Weaver index $[47,48]$. Species grown in the home gardens were classified into eight categories: aromatic, bulb, cereal, fruit, grass, bulb vegetable, legume, and tuber. An analysis of variance (ANOVA), using linear models [44], was carried out to estimate 
the differences in the characteristics of the home gardens according to the households' livelihood strategies. The analysis was made using InfoStat version 2019 [45]. Finally, a network graph was generated to relate the species grown in home gardens by type of rural household in the department of Huila, Colombia; the UCINET software was used for this purpose [49].

\subsection{Push and Pull Factors towards Self-Provisioning in Rural Households}

The community capitals endowment was characterized for each household, using the seven capitals proposed by Flora et al. [37]: human (HC), natural (NC), cultural (CC), built (BC), social (SC), political (PC), and financial (FC) using 44 variables selected from those recommended by different authors [38-40]. This approach makes it possible to analyze the assets that communities or households have, which become the inputs for positive change and household well-being [43]. We identified the capitals that function as aid or impede self-provisioning in rural households. A Spearman correlation analysis was carried out between the capital variables and self-provisioning of food variables and diversity of home gardens in rural households. Significant $(p<0.05)$ positive correlations were considered as aids, whilst negative correlations were impediments to self-provisioning.

\section{Results}

\subsection{Food Sources and Access in Rural Households}

The source of the food consumed in each household was significantly different $(p<0.0001)$ among household types. For the entire sample foods consumed are acquired in grocery stores $(79 \%)$, own crops $(10 \%)$, farmers' markets $(8 \%)$, and barter with neighbors $(3 \%)$. Fruits are acquired in greater proportion from their own crops (agroforestry systems including home gardens); while grains and cereals are acquired mostly in the markets (92 and $89 \%$, respectively). Although most vegetables come from grocery stores $(71 \%)$, $13 \%$ come from farmer's markets and the $9 \%$ farm itself (self-provisioning) (Table 2).

Table 2. Source of food access in rural households in the department of Huila, Colombia.

\begin{tabular}{ccccc}
\hline \multirow{2}{*}{ Variable } & Grocery Stores & Self-Provisioning & Farmers Markets & Neighbors \\
\cline { 2 - 5 } & & & $\%$ & \\
\hline Grains & $92.3 \pm 1.3 \mathrm{a}$ & $0.9 \pm 1.3 \mathrm{~b}$ & $3.7 \pm 1.3 \mathrm{~b}$ & $0.6 \pm 1.3 \mathrm{~b}$ \\
Fruits & $57.5 \pm 2.4 \mathrm{a}$ & $26.7 \pm 2.4 \mathrm{~b}$ & $9.8 \pm 2.4 \mathrm{c}$ & $2.3 \pm 2.4 \mathrm{~d}$ \\
Cereals & $90.4 \pm 1.3 \mathrm{a}$ & $0.3 \pm 1.3 \mathrm{~b}$ & $3.1 \pm 1.3 \mathrm{~b}$ & $0 \pm 1.3 \mathrm{~b}$ \\
Dairy products & $70.3 \pm 2.5 \mathrm{a}$ & $12.2 \pm 2.5 \mathrm{~b}$ & $3.1 \pm 2.5 \mathrm{bc}$ & $8.4 \pm 2.5 \mathrm{c}$ \\
Vegetables & $70.9 \pm 2.2 \mathrm{a}$ & $9.4 \pm 2.2 \mathrm{~b}$ & $13.5 \pm 2.2 \mathrm{~b}$ & $1.8 \pm 2.2 \mathrm{c}$ \\
\hline
\end{tabular}

Values represent the mean \pm standard error. Means with the same letter in a row $(a, b$ or $c)$ do not differ statistically $(p>0.05)$.

The source of food presented differences among types of rural households; the largest percentage of food is purchased in local grocery stores (Figure 2). Diversified Farmers and Livestock Cocoa Farmer households had the highest production of food for selfprovisioning, as opposed to Employees Cocoa Farmers and Landlords Cocoa Farmers, who depend on grocery stores for these goods. Cocoa Farmer households are the largest purchasers of food in farmer's markets (Figure 2).

Rural households in the department of Huila do not have secure access to food, as more than $50 \%$ of rural households indicated that they have had to frequently decrease the amount and variety of food they consumed on a daily basis. Fewer than $25 \%$ of the households reported that none of their members has ever had to go to bed without dinner because of food shortage (traditional dinner in the area: rice, meat, ripe plantain, grain-lentils or beans-and hot sugar cane drink-agua de panela) (Figure 3). 

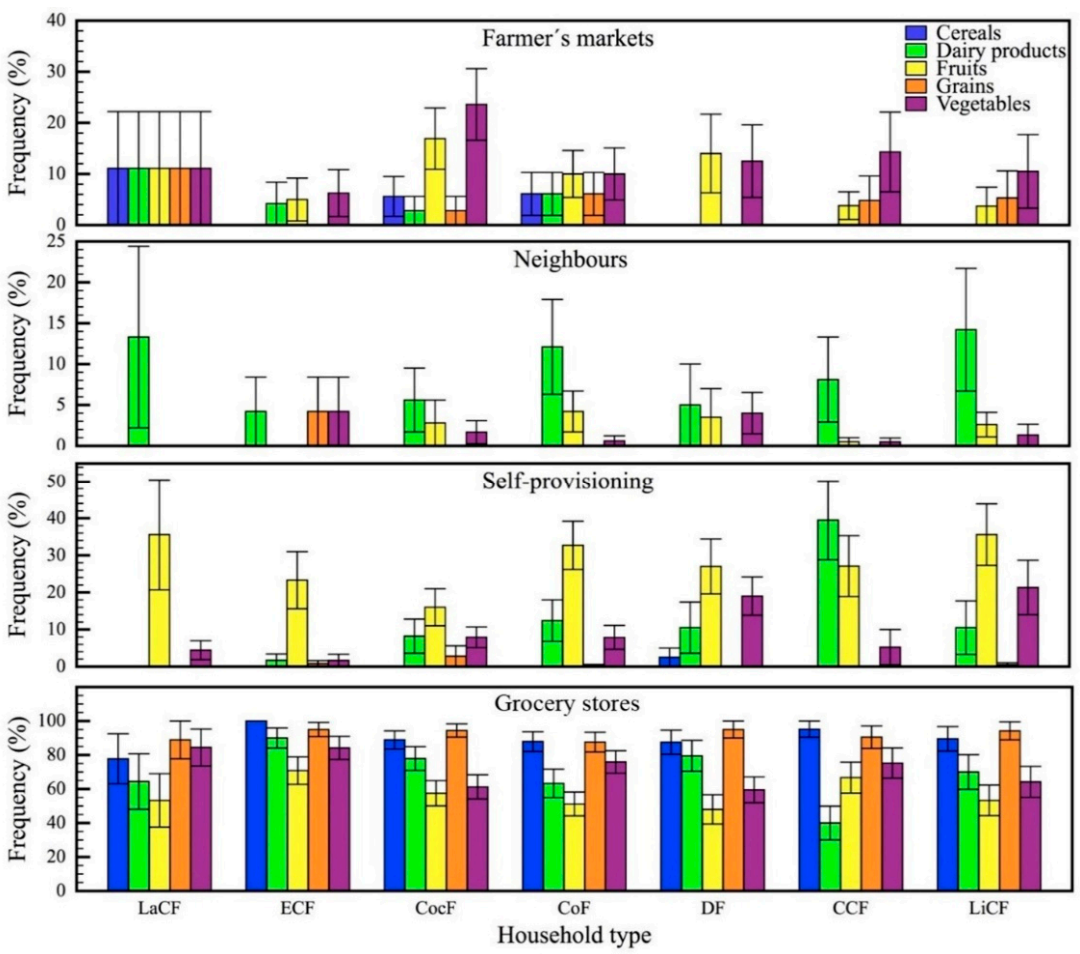

Figure 2. Sources of food access in rural households in department of Huila, Colombia. Landlords Cocoa Farmers (LaCF), Employees Cocoa Farmers (ECF), Cocoa Farmers (CocF), Coffee Farmers $(\mathrm{CoF})$, Diversified Farmers (DF), Cattlemen Cocoa Farmers (CCF), and Livestock Cocoa Farmers $(\mathrm{LiCF})$. The bars represent the mean values, while error bars are standard error.
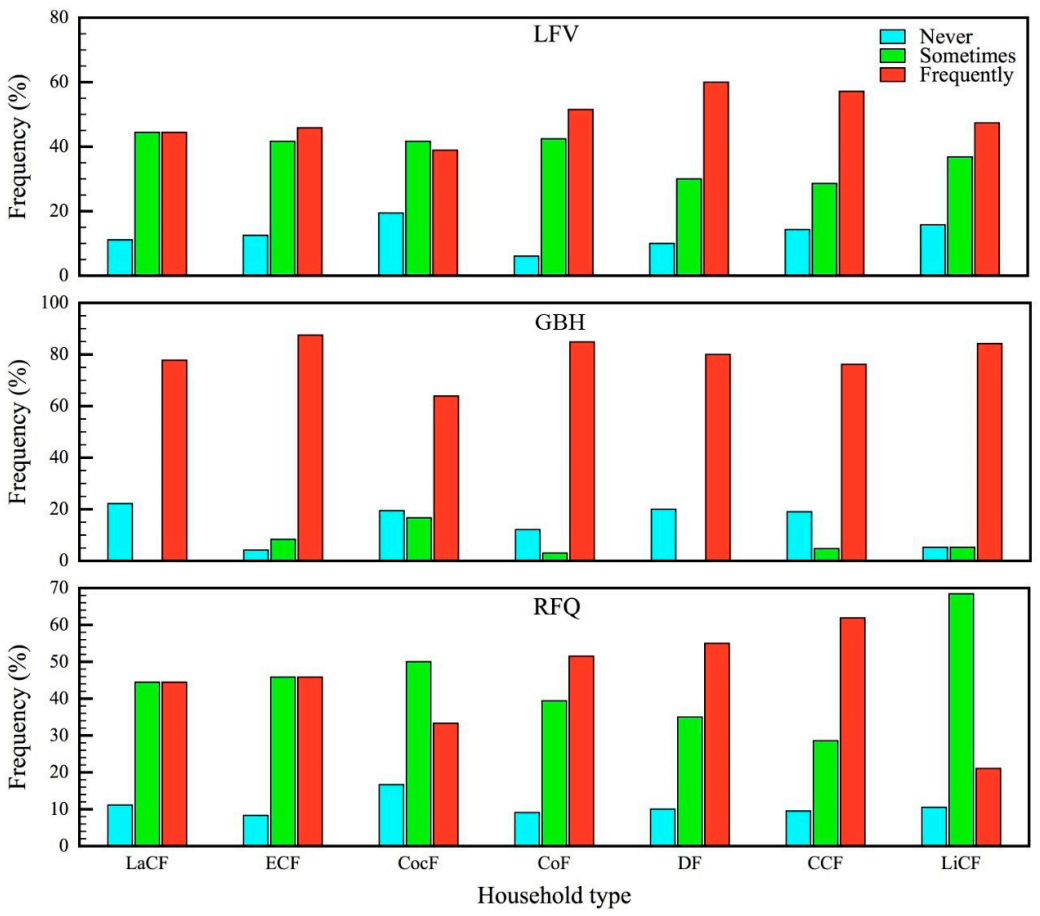

Figure 3. Food access capacity of rural households in department of Huila, Colombia. Limiting food variety (LFV), going to bed without dinner for not having enough food (GBH), Reducing food quantity (RFQ), Landlords Cocoa Farmers (LaCF), Employees Cocoa Farmers (ECF), Cocoa Farmers (CocF), Coffee Farmers (CoF), Diversified Farmers (DF), Cattlemen Cocoa Farmers (CCF), and Livestock Cocoa Farmers (LiCF). 
Diversified Farmer households have never had to decrease the amount of food they eat. They are also producing the most food for their households on their farms (Figure 4). Coffee Farmers decreased the amount of food consumed more frequently and, at the same time, are those who have almost no food production on their farms (Figure 4). Cocoa Farmers, Employees Cocoa Farmers, and Landlords Cocoa Farmers had low food production on their households and frequently must limit food consumption in their household (Figure 4).

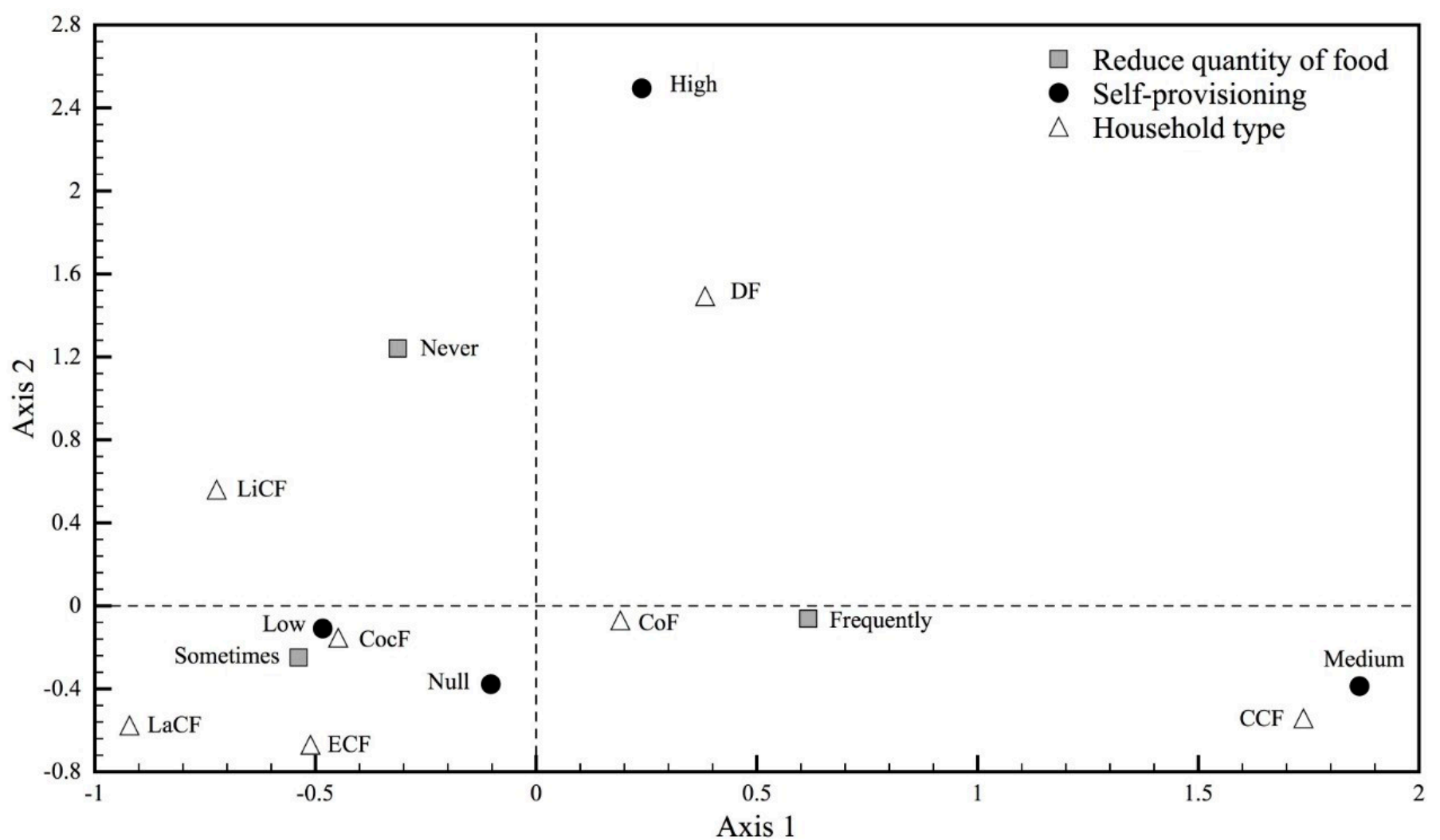

Figure 4. Biplot obtained from a multiple correspondence analysis between household types (white triangle), food access capacity (gray square) and level of self-provisioning (black circle) in the department of Huila, Colombia. Landlords Cocoa Farmers (LaCF), Employees Cocoa Farmers (ECF), Cocoa Farmers (CocF), Coffee Farmers (CoF), Diversified Farmers (DF), Cattlemen Cocoa Farmers (CCF), and Livestock Cocoa Farmers (LiCF).

\subsection{Composition and Botanical Diversity of Home Gardens}

Only $51 \%$ of households have home gardens with between 4 and 13 species of food crops. Livestock Cocoa Farmers households had the most home gardens, followed by Landlords Cocoa Farmers and Coffee Farmers, which contrasts with Employees Cocoa Farmers and Cocoa Farmers, who had the fewest home gardens (Table 3). The home gardens were commonly located in areas close to the dwelling, specifically near the kitchen in the vicinity of the clay oven and stove, as observed in the rural home "Los Naranjos" (Figure 5). This family states that: "the home garden is a blessing, everything is fresh and without those chemicals that are thrown on the crops, and the savings are always a lot" (interviewed producer, 2019).

The proportion of foods grown in home gardens by household types differed statistically $(p<0.05)$. The largest proportion of foods were fruit species, followed by aromatics and bulb species. Bulb species were not grown in home gardens of Cattlemen-Cocoa Farmers. In addition, these households had the lowest proportion of aromatic species, but the highest proportion of fruit species next to the Employees-Cocoa Farmers (Table 3). 
Table 3. Food goods produced in home gardens in different types of rural households in department of Huila, Colombia.

\begin{tabular}{|c|c|c|c|c|c|c|c|c|}
\hline \multirow{2}{*}{\multicolumn{2}{|c|}{ Variable }} & $\mathrm{LaCF}$ & ECF & CocF & $\mathrm{CoF}$ & DF & $\mathrm{CCF}$ & LiCF \\
\hline & & \multicolumn{7}{|c|}{$\%$} \\
\hline \multirow{2}{*}{$\begin{array}{l}\text { Presence of family garden in } \\
\text { the household }\end{array}$} & Yes & 66.8 & 37.5 & 36.1 & 66.7 & 45.0 & 38.1 & 84.2 \\
\hline & No & 33.3 & 62.5 & 63.9 & 33.3 & 55.0 & 61.9 & 15.8 \\
\hline \multirow{8}{*}{ Foods grown in home garden } & Aromatics & 17.6 & 14.3 & 17.8 & 18.7 & 18.7 & 6.7 & 18.2 \\
\hline & Bulb & 11.8 & 4.8 & 22.2 & 15.6 & 18.7 & 0.0 & 9.1 \\
\hline & Cereal & 0.0 & 0.0 & 4.4 & 1.6 & 0.0 & 0.0 & 1.8 \\
\hline & Fruit & 35.3 & 62 & 28.9 & 39.1 & 34.3 & 60 & 32.7 \\
\hline & Grass & 5.9 & 0.0 & 0.0 & 0.0 & 0.0 & 0.0 & 0.0 \\
\hline & Bulb Vegetable & 11.8 & 4.8 & 8.9 & 14 & 15.6 & 6.7 & 18.2 \\
\hline & Legume & 5.9 & 4.8 & 15.6 & 4.7 & 6.2 & 13.3 & 10.9 \\
\hline & Tuber & 11.8 & 9.5 & 2.2 & 6.2 & 6.2 & 13.3 & 9.1 \\
\hline
\end{tabular}

Landlords Cocoa Farmers (LaCF), Employees Cocoa Farmers (ECF), Cocoa Farmers (CocF), Coffee Farmers (CoF), Diversified Farmers (DF), Cattlemen Cocoa Farmers (CCF), and Livestock Cocoa Farmers (LiCF). The grass category is made up of the species Saccharum officinarum $\mathrm{L}$.

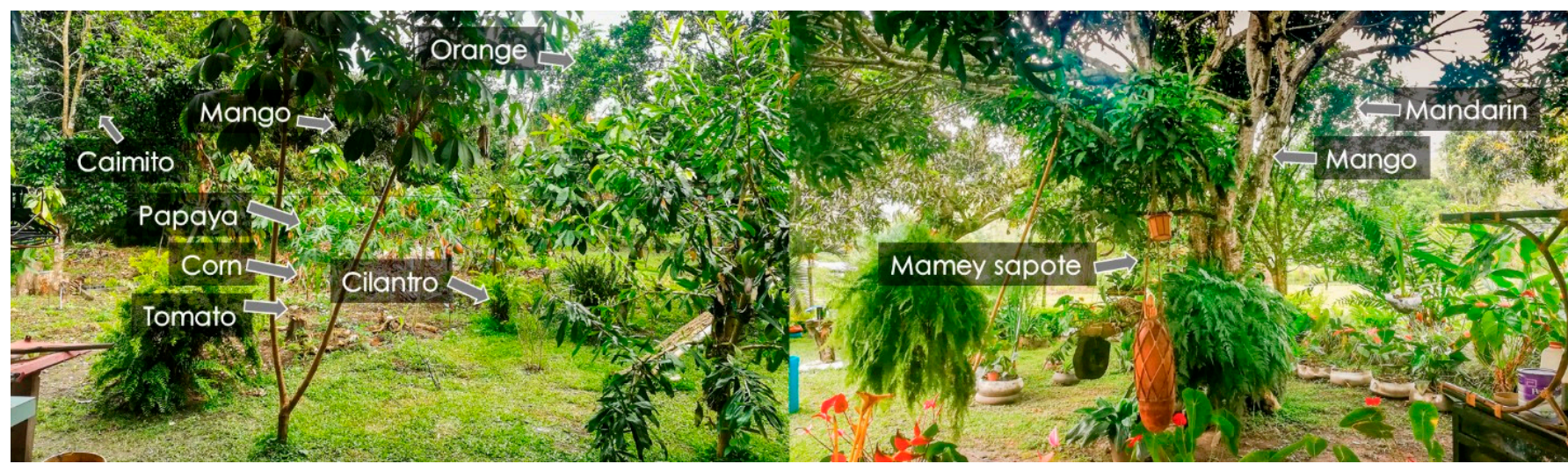

Figure 5. Home gardens in Diversified Farmers' rural household in the department of Huila, Colombia. Orange-Citrus sinensis L. Osbeck; Mandarin-Citrus reticulata L.; Mango-Mangifera indica L.; Caimito-Pouteria caimito (R.\&P.) Radlk; Papaya-Carica papaya L.; Corn-Zea mays L.; Tomato-Solanum lycopersicum L.; Cilantro-Coriandrum sativum L.; Mamey sapote-Pouteria sapota (Jacq.) H.E. Moore and Stearn. Photography from Héctor Eduardo Hernández.

The diversity of food species grown in home gardens showed significant differences $(p<0.05)$ between types of rural households. Livestock-Cocoa Farmers and Cocoa Farmers' households had the greatest Shannon-Weaver index and richness of food species in home gardens; in contrast, Employees-Cocoa Farmers and Cattlemen-Cocoa Farmers households whose home gardens had the least diversity of food species (Table 4).

The most abundant species in the home gardens were: fruit trees (mandarinCitrus reticulata L.; mango-Mangifera indica L.; avocado-Persea americana Mill.; orangeCitrus sinensis L. Osbeck), fruits (tomato-Solanum lycopersicum L.; banana-Musa acuminata L.), leafy vegetables (lettuce-Lactuca sativa L.; chard-Beta vulgaris L.), legumes (Common bean-Phaseolus vulgaris L.), aromatic plants (cilantro-Coriandrum sativum L.), tubers (cassava-Manihot esculenta Crantz), and bulb (onion-Allium cepa L.-) (Figure 6). We found different species in certain types of rural households. The households with the highest number of plant species were CocF, with five species, being (ruta-Ruta graveolens L. strong smelling rue; rosemary—Rosmarinus officinalis L.; arazá-Eugenia stipitata Mc Vaught; lippia alba_Lippia alba (Mill.); spearmint-Mentha spicata) the most common and LaCF and CCF, with three species each. 
Table 4. Diversity of food species produced in home gardens in rural households in the department of Huila, Colombia.

\begin{tabular}{cccccccc}
\hline Variable & LaCF & ECF & CocF & CoF & DF & CCF & LiCF \\
\hline Shannon-Weaver & $0.5 \pm 0.2 \mathrm{abc}$ & $0.3 \pm 0.1 \mathrm{bc}$ & $0.4 \pm 0.1 \mathrm{bc}$ & $0.5 \pm 0.1 \mathrm{ab}$ & $0.5 \pm 0.2 \mathrm{abc}$ & $0.2 \pm 0.1 \mathrm{c}$ & $0.9 \pm 0.2 \mathrm{a}$ \\
Species richness & $2.9 \pm 1.3 \mathrm{ab}$ & $1.3 \pm 0.4 \mathrm{c}$ & $1.7 \pm 0.5 \mathrm{c}$ & $2.9 \pm 0.6 \mathrm{a}$ & $1.9 \pm 0.6 \mathrm{bc}$ & $1.2 \pm 0.4 \mathrm{c}$ & $4.2 \pm 0.9 \mathrm{a}$ \\
Food categories richness & $1.9 \pm 0.7 \mathrm{abc}$ & $0.9 \pm 0.3 \mathrm{~d}$ & $1.2 \pm 0.3 \mathrm{~cd}$ & $1.9 \pm 0.3 \mathrm{ab}$ & $1.6 \pm 0.5 \mathrm{bc}$ & $0.7 \pm 0.2 \mathrm{~d}$ & $2.9 \pm 0.5 \mathrm{a}$ \\
\hline
\end{tabular}

Landlords Cocoa Farmers (LaCF), Employees Cocoa Farmers (ECF), Cocoa Farmers (CocF), Coffee Farmers (CoF), Diversified Farmers (DF), Cattlemen Cocoa Farmers (CCF), and Livestock Cocoa Farmers (LiCF). Food categories: aromatic, bulb, cereal, fruit, grass, bulb vegetable, legume, and tuber. Values represent the mean \pm standard error. Means with the same letter in a row $(a, b, c$ or $d)$ do not differ statistically $(p>0.05)$.

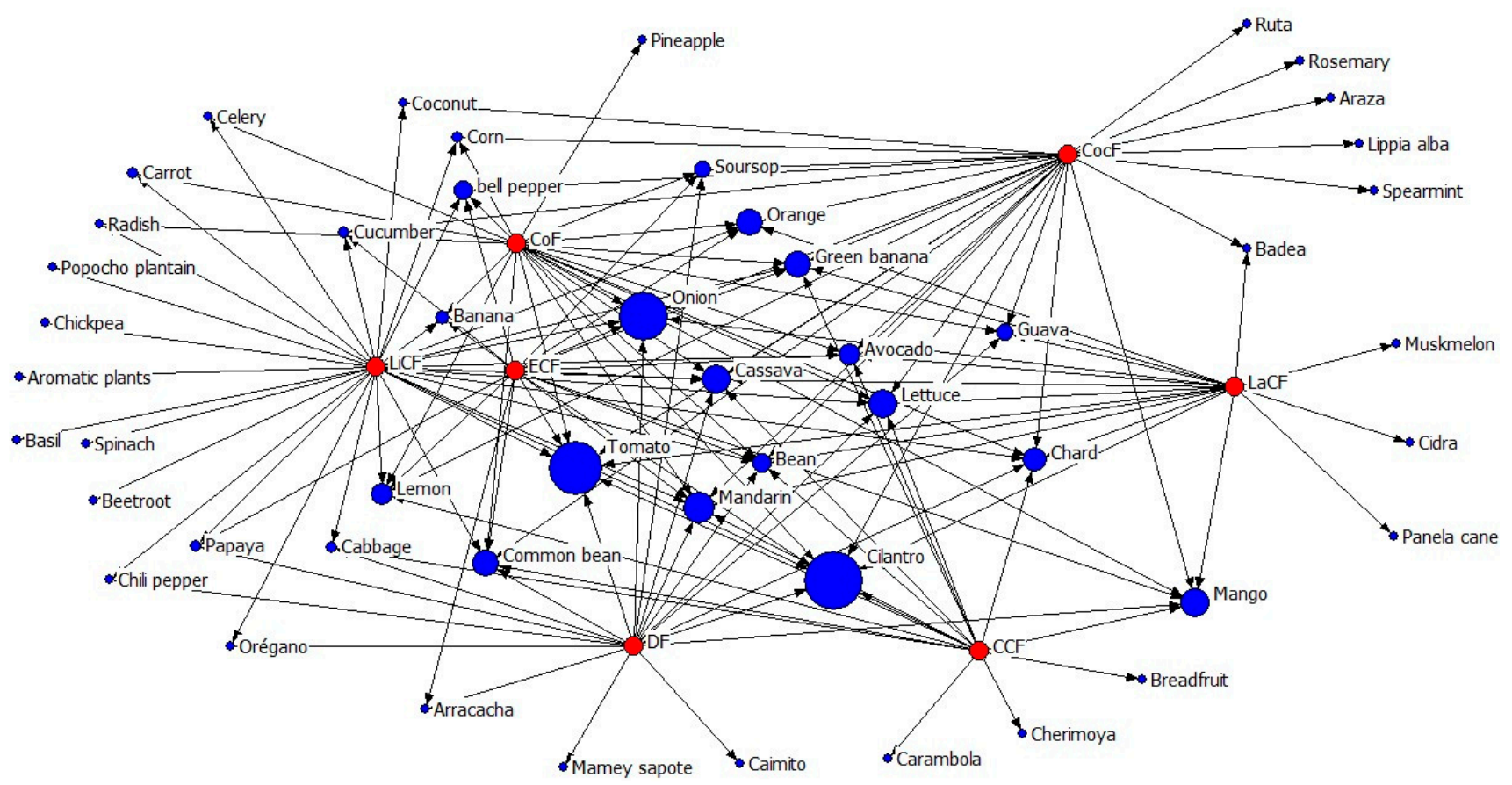

Figure 6. Species grown in home gardens by type of rural household in the department of Huila, Colombia. Red circles represent the types of rural households. Blue circles represent plant species found in rural households. The size of the blue circles represents the number of households that reported each species (larger size equals more households). Cattlemen Cocoa Farmers (CCF), Coffee Farmers (CoF), Cocoa Farmers (CocF), Diversified Farmers (DF), Livestock Cocoa Farmers (LiCF), Employees Cocoa Farmers (ECF), Landlords Cocoa Farmers (LaCF).

\subsection{Push and Pull Factors towards Self-Provisioning in Rural Households}

A significant correlation $(p<0.05)$ was found between variables from four community capitals and the conditions of access to food produced on the farm (agroforestry systems and home gardens) and diversity of food grown in home gardens (Table 5). The greater richness and diversity of species grown in the gardens was related to a greater number of women in the household and a higher level of education among young people and heads of household (human capital), as well as a higher level of technology (tools) (built capital). However, the diversity of species grown in home gardens showed a negative correlation, according to the Spearman coefficient, with farm area (natural capital) and household income (financial capital), particularly with total and external income. The percentage of fruit trees for consumption produced on the farm was positively correlated with the educational level (human capital) and with the households' associations (social capital) (Table 5). Dairy production (milk and cheese) showed a positive correlation with variables of financial and built capital (Table 5). 
Table 5. Correlations between variables that make up capital endowment and variables of self-provisioning of food and diversity of home gardens in rural households in the department of Huila, Colombia.

\begin{tabular}{|c|c|c|c|c|c|c|c|c|}
\hline & \multicolumn{5}{|c|}{ On-Farm Cultivation (Self-Provisioning) } & \multicolumn{3}{|c|}{ Characteristics of the Home Garden } \\
\hline & Vegetables & Grains & Fruits & Cereals & $\begin{array}{l}\text { Dairy } \\
\text { Products }\end{array}$ & $\begin{array}{l}\text { Species } \\
\text { Richness }\end{array}$ & $\begin{array}{c}\text { Group } \\
\text { Richness }\end{array}$ & $\begin{array}{l}\text { Shannon } \\
\text { Weaver }\end{array}$ \\
\hline Human capital & - & - & - & - & - & - & - & - \\
\hline Number of women in the household & - & - & - & - & 0.19 & 0.19 & - & 0.18 \\
\hline Years of education of household head & - & - & 0.3 & - & - & - & - & - \\
\hline Years of youth home education & 0.2 & - & 0.21 & - & - & - & - & - \\
\hline Social capital & - & - & - & - & - & - & - & - \\
\hline Participation in associations & - & - & 0.21 & - & - & - & - & - \\
\hline Interaction with training institutions & 0.29 & - & 0.22 & - & - & - & - & - \\
\hline $\begin{array}{l}\text { Number of trainings received } \\
\text { Natural capital }\end{array}$ & - & - & 0.19 & - & - & -0.29 & - & - \\
\hline Area of the farm & -0.28 & - & - & - & 0.29 & -0.18 & -0.23 & -0.22 \\
\hline Built capital & - & - & - & - & - & - & - & - \\
\hline Access to irrigation system & - & 0.21 & - & - & - & - & - & - \\
\hline Technological level of the farm & - & - & - & - & 0.19 & 0.21 & 0.22 & 0.24 \\
\hline Financial capital & - & - & - & - & - & - & - & - \\
\hline Income households & -0.25 & - & - & - & 0.44 & -0.21 & -0.23 & -0.2 \\
\hline External income & - & - & - & - & - & - & -0.25 & -0.26 \\
\hline Livestock income & - & - & - & - & 0.4 & - & - & - \\
\hline Crop income & -0.2 & - & - & - & 0.26 & -0.19 & - & - \\
\hline Diversity of agricultural activities & 0.3 & - & - & 0.19 & 0.2 & - & - & - \\
\hline
\end{tabular}

Positive significant Spearman correlations $(p<0.05)$ are in blue and negative significant correlation are in red. Darker color shows higher correlation.

\section{Discussion}

\subsection{Food Sources and Access in Rural Households}

The national agricultural census in Colombia indicates that $56 \%$ of rural properties present at least one home garden for self-provisioning, whereas only $27 \%$ of Huila households had home gardens [35]. Our results have found that $51 \%$ of the farms identified in the ten municipalities sampled in the department of Huila had home gardens. These results are far from the findings of Salcedo [50], who mentions that in this department the practice of producing food for self-provisioning is not common in rural households. According to Andrade [51], state policies and the promotion of business agents have consolidated an economic model focused on mining, hydrocarbons, and agro-industry in Huila, which could move rural households away from these traditional practices. Agro-industry has similar characteristics to those promoted in the Brazilian Amazon, where changes in agricultural practices for the mass production of acai (Euterpe precatoria Mart.) fruit have deteriorated agrobiodiversity [52].

The combination of policies that promote agro-industry as an alternative model for the growth of agriculture has degraded the diversification of practices aimed at selfprovisioning, which explains why $79 \%$ of family food comes from direct purchases in grocery stores. Only $8.6 \%$ of food is produced on the farm, which generates a high dependency on external food purchases [1]. This behavior is consistent with the findings of Álvarez et al. [2], who indicate that a significant proportion of farmers in Colombia specialize in the production of a single product, such as bananas, coffee, sugarcane, among others, and restrict efforts to cultivate their own land. This behavior is substantially different from the results obtained by Sovová et al. [53], who estimated a supply of $36 \%$ of vegetables, $28 \%$ of tubers, and $34 \%$ of fruits from home gardens in families in the Czech Republic.

The food supply of rural households is highly dependent on food from outside the farms. This situation compromises the food security of families, especially in the face of social protest events that prevent the mobility of food [54]. These events are increasingly frequent, according to Pérez-Rincón et al. [55], Colombia as of May 2017, had reported 122 social conflicts due to ecological causes, among the most common, rejection of mining $(34 \%)$, hydrocarbon extraction ( $23 \%)$, and access to water $(12 \%)$. The common denominator 
of these conflicts has been the total or intermittent blocking of roads, which prevents the normal movement of food and its arrival at marketplaces.

Another pressing scenario for food security is climate change, which directly affects crop conditions and generates an increase in the presence and attack of pests and diseases [52], as well as the prevalence of inadequate crop management practices, which lack climate change adaptation measures and, therefore, deteriorate the future capacity of soils for sustainable food production [56]. This complex scenario is aggravated by the excessive population growth and the reduction in agricultural land due to the expansion of cities and industrialization fronts [57]. The concentration of population in urban areas transforms large biologically active areas into sources of air, soil, surface water, and groundwater pollution in a phenomenon known as "heat islands", which, in turn, in the face of climate variability events, increases the volume and speed of runoff, causing heavy flooding [58]. A study in Bogotá, Colombia, shows how an increase in precipitation (100 $\mathrm{mm}$ per year) and temperature $\left(2.1^{\circ} \mathrm{C}\right)$ by 2050 compromises both the capacity to supply food to the city and the livelihoods of rural families [59]. These changes in climate pose enormous challenges for agriculture [60]. Challenges that must be taken up as the population grows and with it the pressure for an increasing demand for food [61]; food that will have to be produced at the cost of the inevitable deterioration of natural resources and thus of the future capacity of the soil to produce food [62]. In addition, the alteration of ecosystems will bring with it the proliferation of disease vectors that will directly affect the most vulnerable population [63]. However, external impacts do not generate homogeneous effects in rural communities. Hanazaki et al. [64] found that vulnerability to food insecurity depends on the diversity of household livelihoods. For example, households with a greater diversity of livelihoods, which in our study are the Diversified Farmers, produce a greater quantity and diversity of food that they use for self-consumption.

\subsection{Composition and Diversity of Home Gardens}

For this study, one out of every two households have home gardens on their property; however, the agrobiodiversity of cultivated species is lower than that reported in other studies conducted in the same area of our study (department of Huila) [50,60]. To determine the total number of cultivated species, the species found in the 162 rural households sampled were summed to obtain a diversity of 52 cultivated species, a figure lower than that reported by a similar study conducted in the department of Cauca, in the Andean region of southern Colombia, where a diversity of 142 plant species was found in a total of 120 families sampled [60]. Villa and García [61] in the municipality of San Pablo, middle Magdalena in Colombia, found a total of 75 plant species in 20 home gardens. These statistics are even more critical when compared with the agrobiodiversity of other Latin American countries, such as Mexico, where a study conducted in 180 agroecosystems with home gardens reported a total of 134 tree and shrub species and 54 herbaceous and vegetable species [62].

In the department of Huila, apart from the agro-industrial model promoted by the state, predominant crops, such as coffee, have low species diversity, given the elimination of associated crops such as corn, because it reduces the productivity of coffee [50]. According to Cerdán et al. [65], the richness of species and intensity in the management of coffee cultivation is influenced by farmers' knowledge. The industrialization of agriculture and the spread of standardized technology packages has lowered the level of traditional knowledge of farmers [66]. The absence of home gardens, as an indispensable practice in family farming, exposes a high degree of vulnerability to the loss of agrobiodiversity of food species, as well as traditional knowledge that threatens food security [67].

\subsection{Push and Pull Factors towards Self-Provisioning in Rural Households}

The richness and diversity of cultivated species in the home gardens was associated with a greater number of women in the households and a higher level of education, measured by the sum of the number of years of basic, secondary, or higher education 
completed by rural household members. In the case of the role of women, it coincides with that proposed by Galluzzi et al. [29], who identify women as seed custodians. A study in the southern Andean region of Colombia shows that women are leaders in the production and management of mixed gardens at the local level [68]. These results show the importance of women's participation in home garden management, not only for socio-economic wellbeing, but also for the importance of their practices in sustaining the livelihoods of their communities and preserving agrobiodiversity [20]. In addition, Gutiérrez-Montes et al. [69] state that when women carry out home gardening activities, natural resource conservation actions increase. The importance of the level of education is consistent with studies, which have demonstrated the positive influence of the education of heads of household on dietary outcomes or family nutrition [70,71]. For example, Aweke et al. [1] found that household head literacy correlated positively with levels of self-provisioning.

In Colombia, $54 \%$ of the dispersed rural population has basic primary education, $10 \%$ has secondary education and just $2.7 \%$ has higher education [35], which reflects the limited opportunities for access to economic and social integration of the rural population [72]. By 2019, the transit of young people from middle school to higher education was $39 \%$ [73]. Among the sampled households, the higher the educational level, the greater the richness and diversity of the home gardens. This marks a close relationship between the level of education and knowledge in the management of agricultural practices. Snoeck et al. [74] state that the deficiency in knowledge of sustainable management practices contributes to environmental degradation processes and a reduction in the productive capacity of crops. A basic knowledge of soil management practices is an important factor in maintaining the agricultural viability of the soil and the productivity of rural households [75]. A study conducted in Poland showed that the improvement in the profitability of apple orchard production is conditional on the availability of knowledge on the management of innovative agricultural practices [76]. A prospective study found that farmers' intention to apply sustainable practices in their crops is associated with their ability to manage the sustainability scheme with their own knowledge [77]. As a product of their experiences and phenomena experienced in their crops, farmers have managed to consolidate an intimate and well-developed knowledge system [75], through which they can cope and adapt to changing environments, such as climate change, or other strictly agricultural [78]. However, it is essential to integrate the scientific knowledge produced by academic learning with the local knowledge of farmers [66]. This new interaction of participatory learning and development is referred to as knowledge co-creation and is rapidly gaining recognition in science and in the agroecology movement [79].

The present study found a negative relationship between the farm area and financial income with self-provisioning, different from that found by Lopéz et al. [80]. They found that Mexican households with greater access to land guarantee the provision of food through production in home gardens. The difference can be explained by the effect generated by the high production of agricultural monocultures and extensive cattle raising, common agricultural production techniques in rural households in the department of Huila. Consistent with this, Aweke et al. [1] found a close correlation between livestock and reduced self-provisioning, noting that livestock are not maintained primarily as a source of food for the household, but as a source of cash income. However, the same authors indicate that livestock farming leads to a higher consumption of milk and its derivatives, as we found in Huila and, in addition, the income obtained from the sale of livestock or livestock products is used to buy food. The low level of self-provisioning in Coffee Farmers' households is probably because most of the farm's productive area is devoted to coffee cultivation [50]. This phenomenon is also observed in cocoa production, when it specializes in the cultivation of cocoa, suppressing important companion species for food security $[81,82]$. It is not known that both coffee and cocoa have been cultivated under agroforestry systems that allow for a greater diversity of food species [13], mostly fruits [83,84]. Crops in agroforestry systems and fruit trees grown in the home garden explain the higher percentage of self-provisioning food in the seven types of rural households. This situation 
has been discussed by the IPCC, conceptualizing the need to maintain a balance between locally produced and imported food [85]. Such is the case of coffee and cocoa production in the department of Huila.

\section{Conclusions}

We found that agricultural production for self-provisioning in rural households is minimal and varies according to livelihood strategy. Only half of rural households have home gardens, which, in turn, have a low diversity of food plant species. Therefore, the highest percentage of food comes from grocery stores, and it is necessary to buy it with cash; money that is acquired through agricultural, livestock or external activities. In other words, households have land where they could grow their own food, but they do not. They prefer to have few agricultural or livestock activities, such as, for example, only growing coffee or raising cattle, and with the income generated, they buy their food.

The high external dependence on food exacerbates the vulnerability of each household's food security. If a household's income is compromised by a decrease in agricultural crops or the loss of profitability due to the instability of agricultural product prices, it limits the purchasing power of families. In addition, common cases, such as social problems or climatic events that affect mobility on the roads, prevent the movement of food from the producing areas. These two situations, which occur independently or in some cases together, restrict access to food. This is a major problem, considering that producers have the land resources to produce their own food.

The type of livelihood strategy and the endowment of community capitals, especially human, social, built, and financial, affect the conditions of self-provisioning and the diversity of food in the home gardens. Conditions that are often the main objective of rural development programs, such as improving the economic income of families, turn out to be contradictory to the capacity to produce the food itself. For example, the larger the area to grow crops or keep livestock and the better the economic income, the greater the external dependence on food.

In Huila, we found a positive relationship between the participation of women and the educational level of household members with respect to the increase in food production for self-provisioning. Therefore, it is recommended to strengthen rural education processes, both with the immersion of young people in technological education and higher education programs, as well as in continuing education (courses, field schools, diploma courses). In addition, our results sought not only to have a multiplier effect, but also a ripple effect in other communities, trying to connect local communities and their economies. In the end, the applied results will allow us to address not only food security issues, but also the well-being of the communities, providing inputs that can be used by decision-makers to reduce the risk of increasing food insecurity due to external factors.

Finally, it is important that future research address questions such as: What role can children and young people play in food production for self-sufficiency in their homes? How can the curricula of basic education in rural institutions use food production practices as an educational tool? for example, through production in the school garden, which is an everyday environment for the student, to teach mathematics, natural sciences, or other areas.

Author Contributions: Conceptualization, H.E.H., G.A.G., A.P.B. and J.C.S.; methodology, H.E.H., I.G.-M., F.C., G.A.G., A.P.B. and J.C.S.; software, H.E.H., F.C., H.J.A. and J.C.S.; validation, H.E.H., F.C. and J.C.S.; formal analysis, H.E.H., I.G.-M., F.C., G.A.G., A.P.B., H.J.A. and J.C.S.; investigation, H.E.H., G.A.G., A.P.B. and J.C.S.; resources, H.E.H., G.A.G. and J.C.S.; data curation, H.E.H., F.C. and J.C.S.; writing—original draft preparation, H.E.H. and G.A.G.; writing—review and editing, I.G.-M., F.C., H.J.A., C.B.F. and J.C.S.; visualization, I.G.-M., F.C., H.J.A., C.B.F. and J.C.S.; supervision, I.G.-M., F.C., H.J.A., C.B.F. and J.C.S.; project administration, H.E.H., G.A.G. and J.C.S.; funding acquisition, H.E.H. All authors have read and agreed to the published version of the manuscript.

Funding: This research received no external funding. 
Institutional Review Board Statement: The study was conducted in accordance with the Declaration of Helsinki, and approved by the Research and Postgraduate Committee of the Universidad de la Amazonia (protocol code 600.6.577).

Informed Consent Statement: Informed consent was obtained from all subjects involved in the study.

Data Availability Statement: Not applicable.

Acknowledgments: The authors wish to thank the rural households in the department of Huila that supported the research.

Conflicts of Interest: The authors declare no conflict of interest.

\section{References}

1. Aweke, C.S.; Lahiff, E.; Hassen, J.Y. The contribution of agriculture to household dietary diversity: Evidence from smallholders in East Hararghe, Ethiopia. Food Secur. 2020, 12, 625-636. [CrossRef]

2. Álvarez, M.C.; Mancilla, L.P.; Cortés, J.E. Caracterización socioeconómica y seguridad alimentaria de los hogares productores de alimentos para el autoconsumo, Antioquia-Colombia. Agroalimentaria 2007, 25, 109-122.

3. Sacco dos Anjos, F.; Eduardo, D.G.M.; Velleda, N. La seguridad alimentaria bajo otra mirada: Análisis sobre la evolución de la población brasileña ocupada en actividades de autoconsumo. Investig. Geográficas 2010, 73, 103-118.

4. Dutra, L.V.; Morais, D.C.; Santos, R.H.S.; Franceschini, S.; Priore, S.E. Contribution of the production for self-consumption to food availability and food security in households of the rural area of a Brazilian city. Ecol. Food Nutr. 2018, 57, 282-300. [CrossRef]

5. Torres, L.E. Autoconsumo y reciprocidad entre los campesinos andinos: Caso Fómeque. Cuad. Desarro. Rural 2002, 48, 79-96.

6. Grisa, C. A produção para autoconsumo na agricultura familiar: Uma análise a partir da teoria da sociedade de Risco. Varia Sci. 2008, 8, 171-200.

7. Van der Ploeg, J.D. Peasant-driven agricultural growth and food sovereignty. J. Peasant. Stud. 2014, 41, 999-1030. [CrossRef]

8. Rosset, P.M.; Sosa, B.M.; Jaime, A.M.; Lozano, D.R. The Campesino-to-Campesino agroecology movement of ANAP in Cuba: Social process methodology in the construction of sustainable peasant agriculture and food sovereignty. J. Peasant. Stud. 2011, 38, 161-191. [CrossRef]

9. Altieri, M.A.; Toledo, V.M. The agroecological revolution in Latin America: Rescuing nature, ensuring food sovereignty and empowering peasants. J. Peasant. Stud. 2011, 38, 587-612. [CrossRef]

10. García, J.C.; Gutiérrez, J.G.; Balderas, M.Á.; Araújo, M.R. Estrategia de vida en el medio rural del altiplano central mexicano: El huerto familiar. Agric. Soc. Desarro 2016, 13, 621-641.

11. Anderzén, J.; Luna, A.G.; Luna-González, D.V.; Merrill, S.C.; Caswell, M.; Méndez, V.E.; Jonapá, R.H. Effects of on-farm diversification strategies on smallholder coffee farmer food security and income sufficiency in Chiapas, Mexico. J. Rural Stud. 2020, 77, 33-46. [CrossRef]

12. Altieri, M.A.; Funes, F.R.; Petersen, P. Agroecologically efficient agricultural systems for smallholder farmers: Contributions to food sovereignty. Agron. Sustain. Dev. 2012, 32, 1-13. [CrossRef]

13. Vaast, P.; Somarriba, E. Trade-offs between crop intensification and ecosystem services: The role of agroforestry in cocoa cultivation. Agrofor. Syst. 2014, 88, 947-956. [CrossRef]

14. Kortright, R.; Wakefield, S. Edible backyards: A qualitative study of household food growing and its contributions to food security. Agric. Hum. Values 2011, 28, 39-53. [CrossRef]

15. Aworinde, D.; Erinoso, S.; Ogundairo, B.; Olanloye, A. Assessment of plants grown and maintained in home gardens in Odeda area Southwestern Nigeria. J. Hortic. For. 2013, 5, 29-36. [CrossRef]

16. Algert, S.J.; Baameur, A.; Diekmann, L.O.; Gray, L.; Ortiz, D. Vegetable Output, Cost Savings, and Nutritional Value of Low-Income Families' Home Gardens in San Jose, CA. J. Hunger. Environ. Nutr. 2016, 11, 328-336. [CrossRef]

17. Díaz-Reviriego, I.; González-Segura, L.; Fernández-Llamazares, Á.; Howard, P.; Molina, J.L.; Reyes-García, V. Social organization influences the exchange and species richness of medicinal plants in Amazonian homegardens. Ecol. Soc. 2016, 21. [CrossRef]

18. Calvet, L.; Calvet, M.; Molina, J.L.; Reyes, V. Seed Exchange as an Agrobiodiversity Conservation Mechanism. A Case Study in Vall Fosca, Catalan Pyrenees, Iberian Peninsula. Ecol. Soc. 2012, 17, 29. [CrossRef]

19. Altieri, M.A.; Nicholls, C. Agroecología: Potenciando la agricultura campesina para revertir el hambre y la inseguridad alimentaria en el mundo. Rev. Econ. Crítica 2010, 10, 62-74.

20. Akhter, S.; Alamgir, M.; Sohel, M.S.I.; Rana, M.P.; Ahmed, S.J.M.; Chowdhury, M.S.H. The role of women in traditional farming systems as practiced in homegardens: A case study in Sylhet Sadar Upazila, Bangladesh. Trop. Conserv. Sci. 2010, 3, 17-30. [CrossRef]

21. Calvet, L.; Calvet, M.; Vaqué, L.; Reyes, V. Landraces in situ Conservation: A Case Study in High-Mountain Home Gardens in Vall Fosca, Catalan Pyrenees, Iberian Peninsula. Econ. Bot. 2011, 5, 146-157. [CrossRef]

22. Gray, L.; Guzman, P.; Glowa, K.M.; Drevno, A.G. Can home gardens scale up into movements for social change? The role of home gardens in providing food security and community change in San Jose, California. Local Environ. 2014, 19, 187-203. [CrossRef]

23. Galhena, D.H.; Freed, R.; Maredia, K. Home gardens: A promising approach to enhance household food security and wellbeing. Agric. Food Secur. 2013, 2, 8. [CrossRef] 
24. Lope, D.; Howard, P. The Structure, Composition, and Functions of Homegardens: Focus on the Yucatán Peninsula. Etnoecológica 2012, 9, 17-41.

25. Sovová, L.; Veen, E.J. Neither Poor nor Cool: Practising Food Self-Provisioning in Allotment Gardens in the Netherlands and Czechia. Sustainability 2020, 12, 5134. [CrossRef]

26. Vávra, J.; Daněk, P.; Jehlička, P. What is the contribution of food self-provisioning towards environmental sustainability? A case study of active gardeners. J. Clean. Prod. 2018, 185, 1015-1023. [CrossRef]

27. Cano, E.J. Huertos familiares: Un camino hacia Soberanía Alimentaria. Rev. Pueblos Front. Digit. 2016, 10, 70-91. [CrossRef]

28. Ghosh, S. Measuring sustainability performance of local food production in home gardens. Local Environ. 2014, $19,33-55$. [CrossRef]

29. Galluzzi, G.; Eyzaguirre, P.; Negri, V. Home gardens: Neglected hotspots of agro-biodiversity and cultural diversity. Biodivers. Conserv. 2010, 19, 3635-3654. [CrossRef]

30. Gálvez, M.D.C.A.; Gordillo, G.D.C.A.; Solana, E.E. Prácticas de alimentación y salud entre trabajadores agrícolas migrantes en Miguel Alemán, Sonora, México. Población Salud Mesoamérica 2019, 17, 201-224. [CrossRef]

31. Carney, J.A. Subsistence in the Plantationocene: Dooryard gardens, agrobiodiversity, and the subaltern economies of slavery. J. Peasant. Stud. 2020, 48, 1075-1099. [CrossRef]

32. FAO. La Seguridad Alimentaria: Información Para la Toma de Decisiones; Programa CE-FAO 2011. Available online: https:/ /www.fao. $\mathrm{org} / 3$ /al936s/al936s00.pdf (accessed on 12 January 2022).

33. Lopez Feldman, A.J.; Hernández Cortés, D. Cambio climático y agricultura: Una revisión de la literatura con énfasis en América Latina. El Trimest. Económico 2016, 83, 459-496. [CrossRef]

34. IDEAM. Atlas Climatológico de Colombia; Instituto de Hidrología, Meteorología y Estudios Ambientales—IDEAM: Bogotá, Colombia, 2017.

35. DANE. 3er Censo Nacional Agropecuario. Hay Campo Para Todos; Tomo 2; Departamento Administrativo Nacinal de Estadísticas (DANE): Bogotá, Colombia, 2016.

36. Bernal, A.P.; Hernández-Núñez, H.E.; Suárez, J.C.; Gutiérrez, I.; Casanoves, F.; Flora, C. Vulnerability to climate variability: Analysis from rural household livelihood strategies in Colombia. Unpublished data.

37. Flora, C.; Flora, J.; Fey, S. Rural Communities: Legacy and Change, 2nd ed.; Westview Press: Boulder, Colorado, 2004.

38. Gutiérrez-Montes, I.; Emery, M.; Fernandez-Baca, E. The Sustainable Livelihoods Approach and the Community Capitals Framework: The Importance of System-Level Approaches to Community Change Efforts. Community Dev. 2009, 40, 106-113. [CrossRef]

39. Gómez, C.C.; Gutiérrez-Montes, I.; Imbach, A.; Alpízar, F.; Windevoxhel, N. Tiburón ballena y bienestar comunitario en Holbox, Quintana Roo, México. Recur. Nat. Ambiente 2008, 55, 10-117.

40. Gutiérrez-Montes, I. Healthy Communities Equal Healthy Ecosystems? Evolution (and Breakdown) of a Participatory Ecological Research Project towards a Community Natural Resource Management Process, San Miguel Chimalapa (Mexico); Iowa State University: Ames, IA, USA, 2005.

41. Hernández-Núñez, H.E.; Gutiérrez-Montes, I.; Bernal-Núñez, A.P.; Gutiérrez-García, G.A.; Suárez, J.C.; Casanoves, F.; Flora, C.B. Cacao cultivation as a livelihood strategy: Contributions to the well-being of Colombian rural households. Agric. Hum. Values 2021, 1-16. [CrossRef]

42. Gutiérrez-Montes, I.; Siles, J.; Bartol, P.; Imbach, A. Merging a Landscape Management Planning Approach With the Community Capitals Framework: Empowering Local Groups in Land Management Processes in Bocas del Toro, Panama. Community Dev. 2009, 40, 220-230. [CrossRef]

43. Lachapelle, P.R.; Gutiérrez-Montes, I.; Flora, C. Community Capacity and Resilience in Latin America through the Community Capitals Lens. In Community Capacity and Resilience in Latin America; Lachapelle, P.R., Gutiérrez-Montes, I., Flora, C., Eds.; Routledge Publishing: New York, NY, USA, 2020.

44. Di Rienzo, J.; Macchiavelli, R.; Casanoves, F. Modelos Lineales Mixtos: Aplicaciones en InfoStat, 1st ed.; Grupo InfoStat: Córdoba, Argentina, 2011; 193p.

45. Di Rienzo, J.; Casanoves, F.; Balzarini, M.; Gonzalez, L.; Tablada, M.; Robledo, C. Infostat Versión. 2019. Available online: http:/ / www.infostat.com.ar / (accessed on 11 December 2021).

46. Balzarini, M.G.; Gonzalez, L.; Tablada, M.; Casanoves, F.; Di Rienzo, J.A.; Robledo, C.W. InfoStat. Manual del Usuario; Universidad Nacional de Córdoba: Córdoba, Argentina, 2008.

47. Monroy-Martínez, R.; Ponce-Díaz, A.; Colín-Bahena, H.; Monroy-Ortiz, C.; García-Flores, A. Los Huertos Familiares Tradicionales Soporte De Seguridad Alimentaria En Comunidades Campesinas Del Estado De Morelos, MÉxico. Ambiente Sostenibilidad 2016, 6, 33-43. [CrossRef]

48. Corzo, A.R.; Schwartz, N.B. Milpas y huertos de traspatio tradicionales en Petén, Guatemala y el problema de la seguridad alimentaria. Cienc. Soc. Humanid. 2016, 3, 7-24.

49. Borgatti, S.P.; Everett, M.G.; Freeman, L.C. Ucinet for Windows: Software for Social Network Analysis; Analytic Technologies: Boston, MA, USA, 2002.

50. Salcedo, C. Estrategias familiares, trabajo y orígenes de pequeños productores cafeteros en el Huila, Colombia. Cienc. Política 2016, 11, 161-190. [CrossRef]

51. Andrade, J.M. El papel del estado en el origen de las actividades económicas en una región periférica de Colombia: Análisis comparativo entre la minería y la agroindustria. Entornos 2013, 26, 325-333. [CrossRef] 
52. Steward, A. Reconfiguring Agrobiodiversity in the Amazon Estuary: Market Integration, the Açaí Trade and Smallholders' Management Practices in Amapá, Brazil. Hum. Ecol. 2013, 41, 827-840. [CrossRef]

53. Sovová, L.; Jehlička, P.; Daněk, P. Growing the Beautiful Anthropocene: Ethics of Care in East European Food Gardens. Sustainability 2021, 13, 5193. [CrossRef]

54. Archila, M.; García, M.C.; Restrepo, A.M.; Parra, L. Luchas Social en Colombia 2013: Informe Especial del CINEP/Programa Por la Paz; Programa por la Paz (CINEP/PPP): Bogotá, Colombia, 2014.

55. Pérez-Rincón, M.; Vargas-Morales, J.; Martinez-Alier, J. Mapping and Analyzing Ecological Distribution Conflicts in Andean Countries. Ecol. Econ. 2019, 157, 80-91. [CrossRef]

56. Singh, R.; Singh, G.S. Traditional agriculture: A climate-smart approach for sustainable food production. Energy Ecol. Environ. 2017, 2, 296-316. [CrossRef]

57. Wu, W.; Yu, Q.; You, L.; Chen, K.; Tang, H.; Liu, J. Global cropping intensity gaps: Increasing food production without cropland expansion. Land Use Policy 2018, 76, 515-525. [CrossRef]

58. Borowski, P.F. Nexus between water, energy, food and climate change as challenges facing the modern global, European and Polish economy. AIMS Geosci. 2020, 6, 397-421. [CrossRef]

59. Eitzinger, A.; Läderach, P.; Bunn, C.; Quiroga, A.; Benedikter, A.; Pantoja, A.; Gordon, J.; Bruni, M. Implications of a changing climate on food security and smallholders' livelihoods in Bogotá, Colombia. Mitig. Adapt. Strateg. Glob. Chang. 2012, 19, 161-176. [CrossRef]

60. Pathak, T.; Maskey, M.; Dahlberg, J.; Kearns, F.; Bali, K.; Zaccaria, D. Climate Change Trends and Impacts on California Agriculture: A Detailed Review. Agronomy 2018, 8, 25. [CrossRef]

61. Calicioglu, O.; Flammini, A.; Bracco, S.; Bellù, L.; Sims, R. The Future Challenges of Food and Agriculture: An Integrated Analysis of Trends and Solutions. Sustainability 2019, 11, 222. [CrossRef]

62. Kopittke, P.M.; Menzies, N.W.; Wang, P.; McKenna, B.A.; Lombi, E. Soil and the intensification of agriculture for global food security. Environ. Int. 2019, 132, 105078. [CrossRef]

63. Rohr, J.R.; Barrett, C.B.; Civitello, D.J.; Craft, M.E.; Delius, B.; DeLeo, G.A.; Hudson, P.J.; Jouanard, N.; Nguyen, K.H.; Ostfeld, R.S.; et al. Emerging human infectious diseases and the links to global food production. Nat. Sustain. 2019, 2, 445-456. [CrossRef]

64. Hanazaki, N.; Berkes, F.; Seixas, C.S.; Peroni, N. Livelihood Diversity, Food Security and Resilience among the Caiçara of Coastal Brazil. Hum. Ecol. 2012, 41, 153-164. [CrossRef]

65. Cerdán, C.R.; Rebolledo, M.C.; Soto, G.; Rapidel, B.; Sinclair, F.L. Local knowledge of impacts of tree cover on ecosystem services in smallholder coffee production systems. Agric. Syst. 2012, 110, 119-130. [CrossRef]

66. Šūmane, S.; Kunda, I.; Knickel, K.; Strauss, A.; Tisenkopfs, T.; Rios, I.d.I.; Rivera, M.; Chebach, T.; Ashkenazy, A. Local and farmers' knowledge matters! How integrating informal and formal knowledge enhances sustainable and resilient agriculture. J. Rural. Stud. 2018, 59, 232-241. [CrossRef]

67. Montenegro, M.; Lagos, T.C.; Vélez, J. Agrodiversidad de los huertos caseros de la región andina del sur de Colombia. Rev. Cienc. Agrícolas 2017, 34, 50-63. [CrossRef]

68. Guapucal, M.; Benavides, X.S.; Sinisterra, K.X. Valoración participativa del uso y manejo del huerto mixto. Rev. Cienc. Agrícolas 2019, 36, 46-58. [CrossRef]

69. Gutiérrez-Montes, I.; Emery, M.; Fernandez-Baca, E. Why Gender Matters to Ecological Management and Poverty Reduction. In Integrating Ecology and Poverty Reduction; Springer: New York, NY, USA, 2012; pp. 39-59.

70. Vaitla, B.; Cissé, J.D.; Upton, J.; Tesfay, G.; Abadi, N.; Maxwell, D. How the choice of food security indicators affects the assessment of resilience-An example from northern Ethiopia. Food Secur. 2019, 12, 137-150. [CrossRef]

71. Mango, N.; Zamasiya, B.; Makate, C.; Nyikahadzoi, K.; Siziba, S. Factors influencing household food security among smallholder farmers in the Mudzi district of Zimbabwe. Dev. S. Afr. 2014, 31, 625-640. [CrossRef]

72. MEN. Plan Rural de Educación Superior: Estrategias de Fortalecimiento de Capacidades Para el Desarrollo Territorial; Ministerio de Educación Nacional: Bogotá, Colombia, 2018.

73. Viáncha. Análisis del Indicador de Tránsito Inmediato a Educación Superior en Colombia. Available online: https: //luisfernandoviancha.com/index.php/tasa-de-transito/ (accessed on 12 January 2022).

74. Snoeck, D.; Koko, L.; Joffre, J.; Bastide, P.; Jagoret, P. Cacao Nutrition and Fertilization. In Sustainable Agriculture Reviews; Lichtfouse, E., Ed.; Springer: Cham, Switzerland, 2016; Volume 19, pp. 155-202.

75. Dawoe, E.K.; Quashie-Sam, J.; Isaac, M.E.; Oppong, S.K. Exploring farmers' local knowledge and perceptions of soil fertility and management in the Ashanti Region of Ghana. Geoderma 2012, 179-180, 96-103. [CrossRef]

76. Gaworski, M.; Ciesielski, W.; Kaminska, N. Effect of modern apple production technologies on development of family orchard farming with particular focus on Polish conditions. Eng. Rural. Dev. 2017, 24, 408-414.

77. Menozzi, D.; Fioravanzi, M.; Donati, M. Farmer's motivation to adopt sustainable agricultural practices. Bio-Based Appl. Econ. 2015, 4, 125-147. [CrossRef]

78. Naess, L.O. The role of local knowledge in adaptation to climate change. Wiley Interdiscip. Rev. Clim. Chang. 2013, 4, 99-106. [CrossRef]

79. Utter, A.; White, A.; Méndez, V.E.; Morris, K. Co-creation of knowledge in agroecology. Elem. Sci. Anthr. 2021, 9, 00026. [CrossRef] 
80. Lopéz, L.; Alvarez, F.; Rappo, E.; Damián, Á.; Méndez, A.; Paredes, A. Family Gardens and Food Security: The Case of the Municipality of Calpan, Puebla, Mexico. Agric. Soc. Desarro 2019, 16, 351-371.

81. Numbisi, F.N.; Alemagi, D.; Degrande, A.; Van Coillie, F. Farm Rejuvenation-Induced Changes in Tree Spatial Pattern and Live Biomass Species of Cocoa Agroforests in Central Cameroon: Insights for Tree Conservation Incentives in Cocoa Landscapes. Sustainability 2021, 13, 8483. [CrossRef]

82. Notaro, M.; Collado, C.; Depas, J.K.; Dumovil, D.; Denis, A.J.; Deheuvels, O.; Tixier, P.; Gary, C. The spatial distribution and height of associated crops influence cocoa tree productivity in complex agroforestry systems. Agron. Sustain. Dev. 2021, 41, 60. [CrossRef]

83. Cerda, R.; Deheuvels, O.; Calvache, D.; Niehaus, L.; Saenz, Y.; Kent, J.; Vilchez, S.; Villota, A.; Martinez, C.; Somarriba, E. Contribution of cocoa agroforestry systems to family income and domestic consumption: Looking toward intensification. Agrofor. Syst. 2014, 88, 957-981. [CrossRef]

84. Cerda, R.; Avelino, J.; Harvey, C.A.; Gary, C.; Tixier, P.; Allinne, C. Coffee agroforestry systems capable of reducing disease-induced yield and economic losses while providing multiple ecosystem services. Crop Prot. 2020, 134, 105149. [CrossRef]

85. IPCC. Climate Change and Land: An IPCC Special Report on Climate Change, Desertification, Land Degradation, Sustainable Land Management, Food Security, and Greenhouse Gas Fluxes in Terrestrial Ecosystems; Summary for Policymakers; IPCC: Geneva, Switzerland, 2019; p. 41. 